https://doi.org/10.34142/23129387.2020.62.17

УДК: 159.922.5; 159.923.2

ORCID 0000-0003-3962-0795

ORCID 0000-0003-1179-8540

ORCID 0000-0002-3788-1185

ORCID 0000-0002-7531-4843

ORCID 0000-0001-9334-1127

\title{
МЕТОДИКА ДІАГНОСТИКИ ТІЛЕСНОГО ЛОКУСУ КОНТРОЛЮ
}

Тамара Б. Хомуленко ${ }^{\text {IA }}$, Віра О. Крамченкова ${ }^{2 C D}$, Дар'я М. Туркова $^{3 в E}$, Ніна П.Лесніченко ${ }^{4 B E}$, Богдан С.Миронович ${ }^{5 B}$

${ }^{1}$ доктор психологічних наук, професор, завідувач кафедри психології ХНПУ імені Г. С. Сковороди, м. Харків, Украӥна, Еmail: tamarakhom108@gmail.com

${ }^{2}$ доктор психологічних наук, доцент кафедри психологї ХНПУ

імені Г. С. Сковороди, м. Харків, Україна, E-таіl:

kramchenkova@ukr.net

${ }^{3}$ кандидат психологічних наук, стариий викладач кафедри практичної психології Криворізького державного педагогічного університет, м. Кривий Ріг, Украӥна, E-mail: tdariamail@gmail.com

${ }^{4}$ аспірантка кафедри психології ХНПУ імені Г. С. Сковороди, м. Харків, Україна, E-mail:nakaznjuk@gmail.com

${ }^{5}$ аспірант кафедри психології ХНПУ імені Г. С. Сковороди, м. Харків, Украӥна E-mail: bgdmironovich@gmail.com

Метою дослідження було створення психодіагностичної методики для вивчення тілесного локусу контролю. Відповідно до мети дослідження завданнями роботи виступили: операщіоналізація 
феномену тілесний локус контролю та його емпіричних індикаторів, розробка опитувальника як набору тверджень, щз відображують зміст визначених індикаторів, психометрична оцінка, розробленого опитувальника.

Методи дослідження. Психометрична обробка результатів дослідження включалаперевірку внутрішньої узгодженості методики за коефіцієнтом альфа Кронбаха, очінку конструктивної валідності та ретестової надійності опитувальника. Конвергентна та дискримінативна валідність методики перевірялась шлляом визначення кореляційних зв'язків показників методики «Тілесний локус контролю» та методик діагностики ставлення до свого тіла О.Б.Станковської, діагностики локусу контроля Дж. Роттера, діагностики рівня суб'єктивного контролю $Є$. Ф. Бажина, С. А. Голикіної, А. М. Еткінда, опитувальника Body Awareness Questionnaire (конвергентна валідність); діагностики інтрацептивної чутливості, «Вербалізачія тілесного Я» (дискримінантна валідність). Психометричну вибірку склали 286 «умовно здорових» респондентів віком від 15 до 55 років. Прочедура ретестування проводилася через чотири тижні із залученням 96 респондентів, щзо входили до психометричної вибірки.

Результати. Теоретичною основою створення опитувальника діагностики тілесного локусу контролю були конщепџія локусу контролю, конщепції рещиирокного детермінізму та каузальної атрибуції, уявлення про профіль суб'єктивного контролю, уявлення про роль інтернальності у клініці соматичних та психосоматичних розладів, а також зв'язку тілесного досвіду та смислового аспекту особистості, визначення локусу тілесного контролю, як зв'язку локалізачіі тілесних відчуттів із усвідомленням власного психоемочійного стану та ступенем самоконтролю, визначення основних сфер ставлення до тілесного, як ідентифікаторів тілесного локусу контролю. Шляхом деревовидної кластерізачії було виділено статистично значущі класи тверджень, що відповідають 5 сферам ставлення до тілесного: сфера здоров'я і хвороби; сфера краси $i$ зовнішності; сфера харчової поведінки; сфера сексуальної поведінки; сфера фізичної активності і спорту. Опитувальник характеризується інтраіндивідуальною стійкістю та розподілом близьким до нормального, щэо дає підстави для перенесення отриманих 
результатів вибіркової сукупності на генеральну, високою внутрішньою узгодженістю, . Визначені три інтервали граничні значення статистичної норми, щуо характеризують високий, середній та низький рівні показника інтернальності тілесного локусу контролю. Показники конвергентної та дискримінативної валідності свідчать, щзо запропонована методика вимірює саме усвідомлення детермінації особливостей функціонування власного тіла та характеризують приписування внутрішніх або зовнішніх причин того, щзо відбувається з тілом.

Висновки. Запропонована психодіагностична методика «Тілесний локус контролю» відповідає сучасним вимогам до психометричного обтрунтування особистісних опитувальників. Психометричними ідентифікаторами тілесного локусу контролю визначено ставлення до основних сфер тілесного - сфери здоров'я $i$ хвороби; краси $i$ зовнішності, харчової та сексуальної поведінки, фізичної активності $i$ спорту. Стандартизація опитувальника показала його високу тест-ретестову надійність та валідність. Опитувальник може бути використаний для психодіагностики у структурі досліджень з психосоматичної проблематики та реалізачії оздоровчих психотехнологій.

Ключові слова: психодіагностична методика, психосоматичні феномени, психосоматичне здоров'я, рефлексія тілесного, ставлення до тіла, саморегуляиія, тілесний локус контролю.

\section{Methodology of diagnosis of Bodily locus of control} Tamara B. Khomulenko, Vira O. Kramchenkova, Daria M. Turkova, Nina P. Lesnichenko, Bohdan S. Myronovych

${ }^{1}$ Doctor of Psychological Sciences, Professor, Head of the Department of Psychology, H.S. Skovoroda Kharkiv Natinal Pedagogical University,

${ }^{2}$ Doctor of Psychological Sciences, Associate Professor of Psychology, H.S. Skovoroda Kharkiv Natinal Pedagogical University,

${ }^{3}$ Candidate of Psychological Sciences, Senior Lecturer, Department of Practical Psychology, Kryvyi Rih State Pedagogical University, 
4

graduate student of the Department of Psychology, H.S. Skovoroda Kharkiv Natinal Pedagogical University,

${ }^{5}$ graduate student of the Department of Psychology, H.S. Skovoroda Kharkiv Natinal Pedagogical University,

The Aim of the study was to create a psychodiagnostic technique for studying the Bodily locus of control. In accordance with the purpose of the study, the tasks of the work were: operationalization of the phenomenon of Bodily locus of control and its empirical indicators, development of the questionnaire as a set of statements reflecting the content of certain indicators, psychometric evaluation of the developed questionnaire.

Research methods. Psychometric processing of the results of the study included verification of the internal consistency of the method by the Cronbach's alpha coefficient, assessment of structural validity and retest reliability of the questionnaire. The convergent and discriminant validity of the method was checked by determining the correlations between the indicators of the method "Bodily locus of control" and methods of diagnosing the attitude to his body by O.B. Stankovskaya, diagnosing the locus of control J. Rotter, diagnosing the level of subjective control E.F. Bazhina, S.A. Golikina, A.M. Etkind, Bodily Awareness Questionnaire; diagnostics of intraceptive sensitivity, "Verbalization of the bodily self" (discriminant validity). The psychometric sample consisted of 286 "relatively healthy" respondents aged 15 to 55 years. The retest procedure was conducted four weeks later with the involvement of 96 respondents who were included in the psychometric sample.

Results. The theoretical basis for creating a questionnaire for the diagnosis of bodily locus of control were the concept of locus of control, the concept of reciprocal determinism and causal attribution, the profile of subjective control, the role of internality in the clinic of somatic and psychosomatic disorders, and the relationship of bodily experience and semantic aspect, determination of the locus of Bodily control, as a connection of localization of bodily sensations with awareness of one's own psycho-emotional state and degree of self-control, determination of the main spheres of attitude to bodily as identifiers of bodily locus of control. Through tree clustering, statistically significant classes of statements were identified, corresponding to 5 areas of attitude to the body: sphere of health and disease; sphere of beauty and appearance; sphere of food behavior; 
sphere of sexual behavior; sphere of physical activity and sports. The questionnaire is characterized by intra - individual stability and distribution close to normal, which gives grounds for transferring the results of the sample to the general, high internal consistency. Three intervals of limit values of the statistical norm characterizing high, average and low levels of an indicator of internality of a Bodily locus of control are defined. Indicators of convergent and discriminant validity show that the proposed method measures the awareness of the determination of the peculiarities of the functioning of one's own body and characterizes the attribution of internal or external causes of what happens to the body.

Conclusions. The psychodiagnostic method "Bodily locus of control" meets modern requirements for psychometric substantiation of personality questionnaires. Psychometric identifiers of the bodily locus of control determine the attitude to the main spheres of the body - the sphere of health and disease; beauty and appearance, eating and sexual behavior, physical activity and sports. The standardization of the questionnaire showed its high test-retest reliability and validity. The questionnaire can be used for psychodiagnostics in the structure of research on psychosomatic issues and the implementation of health psychotechnologies.

Keywords: psychodiagnostic technique, psychosomatic phenomena, psychosomatic health, bodily reflection, attitude to the body, self-regulation, Bodily locus of control.

Вступ. Психодіагностика феноменів тілесності $\epsilon$ перспективним напрямом наукових розробок. Зростання інтересу до цієї проблематики не є випадковим, оскільки сучасні наукові погляди характеризуються ставленням людини, як психосоматичної цілісності. Критеріями соціального прогресу суспільства все частіше розглядаються: рівень здоров'я, активне довголіття i реалізація людської індивідуальності. Але теоретичному обгрунтуванню та емпіричний розробці проблематики тілесності, механізмам функціонування, особливостям становлення, формування та діагностики феноменів тілесності приділяється недостатньо уваги в дослідженнях 3 психології. Зазвичай у сучасній психології досліджуються окремі аспекти схеми тіла, образа фізичного Я і 
самосприйняття та віддзеркалення певних аспектів почуттів, установок, уявлень (Карелін, 2007; Слісеєв, 2019), але відсутні методики психодіагностики регуляції тілесного, зокрема тілесного локусу контролю.

Категорія «локус контролю» було введене у психологію Дж. Роттером (1966), згідно з визначенням якого, актуальними $є$ два судження. Люди різняться за типом локалізації контролю над значущими для себе подіями i поділяються на екстернальний та інтернальний типи. У першому випадку людина вважає, що події, що відбуваються з нею, є результатом дії зовнішніх сил - випадку, інших людей і т. п. У другому випадку людина інтерпретує значимі події як результат своєї власної діяльності. Будь-якій людині властива певна позиція на континуумі, що тягнеться від екстернального до інтернального типу. Локус контролю, характерний для індивіда, універсальний по відношенню до будь-яких типів подій і ситуацій, з якими йому доводиться стикатися. Один і той же тип контролю характеризує поведінку цієї особи у разі невдач і у сфері досягнень, причому це в рівній мірі торкається різних сфер соціального життя (Повякель, 2005).

На суб'єктивний локус контролю в аспекті тілесності звертають нашу увагу Т. Д. Василенко, А. В. Селин та Ф. Ю. Мангушев (2016). Вони виділяють важливість смислових аспектів тілесного досвіду хронічного соматичного захворювання, вказують на первинність виникнення факту захворювання у тілесних відчуттях, що сприяють захворюванню та сигналізують людині про його виникнення, включаючи механізми когнітивної переробки, так відбувається визначення тілесних відчуттів 3 яких формується симптом хвороби. На думку авторів, у такому випадку саме рефлексивність забезпечує самоконтроль поведінки людини й важливу роль у процесі осмислення відіграє більша вираженість інтернальності чи екстернальності локусу контролю. 
Брак самоконтроль поведінки при виникненні психосоматичних хвороб можемо зустріти й в інших дослідженнях. Так, звернувши увагу на такий різновид психосоматичних захворювань як ожиріння, варто відмітити експериментальне дослідження А. В. Сидорова (2012) щодо стилів харчової поведінки при аліментарному ожирінні. Так, автором виявлений прямий кореляційний зв'язок між змінною «екстернальний стиль харчування», змінною «імпульсивність» $\mathrm{i}$ зворотний зв'язок змінної «екстернальний стиль харчування» зі змінною «чинник Q3 (контроль бажань)» опитувальника Р. Кеттелла. На думку А. В. Сидорова (2012) екстернальний стиль харчової поведінки пов'язаний з підвищеною чутливістю до зовнішніх стимулів споживання їжі, вони набирають низькі оцінки за чинником «самоконтроль поведінки», що вказує на слабку волю і поганий самоконтроль (особливо над бажаннями) і високі оцінки за шкалою імпульсивності.

Т. Д. Василенко, А. В. Селин та Ф. Ю. Мангушев (2016) пояснюють це наступним чином: людина усвідомлює що хвора, визначає своє ставлення до цього факту і розуміє, які наслідки це може нести для неї. Хворий концентрується на факті захворювання, усуваючи на задній план усі інші сфери стосунків і діяльності, що може відбитися на смисловій сфері у вигляді зниження загальної усвідомленості життя, негативної оцінки як актуальної ситуації, так і пройденого життєвого шляху. Таким чином, відбувається процес взаємодії пов'язаного 3 виникненням захворювання тілесного досвіду і смислового компонента особистості. Дані що їм вдалося отримати при вивченні локалізації контролю свідчать про переважання екстернального рівня суб'єктивного контролю в групах iз соматичними захворюваннями.

Так, хворі більшою мірою покладають відповідальність за свій стан на дії інших людей, в даному випадку лікарів. Низькі показники за параметрами «Локус контролю-Я» в групах 3 ішемічною хворобою серця, діабетом, бронхіальною астмою та 
хронічними захворюваннями демонструють переважання уявлення про себе як про особу, не здатну повною мірою контролювати своє життя відповідно до своїх цілей і уявлення про її сенс, а тіло сприймається як перешкода. Автори доходять висновку, що дезадаптивний взаємозв'язок тілесності i смислового аспекту особистості обумовлений блокуванням процесів рефлексії і підвищенням екстерналізації рівня локусу контролю (Василенко, Селин, Мангушев, 2016). Отже, авторами порушено розуміння загального локусу контролю при аналізі смислового аспекту соматичних хвороб.

На відміну від них, М. Сандомірський оперує дифеніцією локусу тілесного контролю. Так, за аналогією до розуміння Дж. Роттером локусу контролю, М. Сандомірський (2005) говорить про локус тілесного контролю, під котрим розуміє локалізацію тілесних відчуттів з якими зв'язується усвідомлення власного психоемоційного стану і контроль емоцій, а також ступінь цього самоконтролю. Область тіла, з якою найбільшою мірою пов'язана наша довільна і особливо мимовільна тілесна увага, себто «епіцентр» кінестетичних відчуттів на думку М. Сандомірського, може переміщатися по серединній лінії тіла, переважно по передній поверхні тулуба. Переміщення фокусу уваги/усвідомлення по цій осі в напрямі від голови до ніг відповідає зростанню міри самоконтролю, емоційної стійкості, «приземленості» і практичності, іноді навіть зайвій поглиненості життєвими реаліями. Переміщення в зворотьому напрямку - натхненню i осяянню, польоту думки i творчої фантазії, але в той же час і більшій емоційній лабільності і чутливості. Тим самим переміщення «локусу усвідомлення» тіла вниз (нижня частина тулуба, ноги) відповідає більшій опорі на власні сили, будучи тілесним аналогом внутрішнього локусу контролю (інтернальності). Переміщення ж його вгору орієнтації на зовнішні авторитети, аналогічно зовнішньому локусу контролю (екстернальності). У контексті нашого дослідження виявилася цікавою думка М. Сандомірського 
(2005) щодо наявності локусу контролю при розгляді тілесності, проте на наше переконання мова моє йти не про локалізацію в розумінні розміщення, а про спрямованість ставлення до власної тілесності що спричинюе чи позбавляє психосоматичних розладів.

Отже, існуючі уявлення про зв'язок локусу контролю із патернами психологічних рис, поведінки та тілесності особистості дозволяють говорити про значущу роль рівня інтернальності тілесного у структурі локусу контролю особистості у психосоматичних розладах та проявах феноменів нормального функціонування організму. Якість психотерапевтичного процесу при соматичних та психосоматичних розладах напряму залежить від ефективності постановки психологічного діагнозу. Таким чином, назріла нестача якісного психодіагностичного інструментарію із заявленої проблематики обумовило необхідність розробити психодіагностичну методику покликану на виявлення типу тілесного локусу контролю особистості.

Метою дослідження $є$ створення психодіагностичної методики для вивчення тілесного локусу контролю. Відповідно до мети дослідження завданнями роботи виступили: операціоналізація феномену тілесний локус контролю та його емпіричних індикаторів, розробка опитувальника як набору тверджень, що відображують зміст визначених індикаторів, психометрична оцінка розробленого опитувальника.

\section{Методологія та методи.}

В процесі психометричної обробки результатів дослідження здійснено перевірку внутрішньої узгодженості методики за коефіцієнтом альфа Кронбаха, оцінку конструктивної валідності та ретестової надійності опитувальника. Конвергентна та дискримінативна валідність методики перевірялась шляхом визначення кореляційних зв'язків показників методики «Тілесний локус контролю» та методик діагностики ставлення до свого тіла О.Б.Станковської 
(2011), діагностики інтрацептивної чутливості (Т. Б. Хомуленко, К. М. Родіної, 2017), «Вербалізація тілесного Я» (Т.Б. Хомуленко, В.О. Крамченкової, 2016), методики діагностики локусу контроля Дж. Роттера (Карелін, 2007), методики діагностики рівня суб'єктивного контролю Є. Ф. Бажина, С. А. Голикіної, А. М. Еткінда (1984), опитувальника, що визначає усвідомленість власного тіла Body Awareness Questionnaire (Shields, S. A., Mallory, M. E., \& Simon, A.,1989).

Конвергентна валідність (від лат. - сходитися до одного центру, конвертувати) — це висновок про подібність (ізоморфізм - гомоморфізм) даного методу (методики, теста, заходу) 3 іншим методом, призначеного для тих же цілей (конвергентного, подібного). Вона виражається у вимозі статистичної залежності діагностичних показників, якщо вони спрямовані на вимірювання концептуально близьких психічних властивостей індивіда (Анастази, Урбина, 2007). Конвергентна валідність нами була виявлена по відношенню до наступних методик:

1. Методика діагностики локусу контроля Дж. Роттера що складається з опитувальника на 29 попарних запитань одному 3 яких необхідно надати перевагу. Діагностика уможливлює визначити інтернальність або екстернальність особистості.

2. Методика діагностики рівня суб'єктивного контролю Є. Ф. Бажина, С. А. Голикіної, А. М. Еткінда, що визначає тип локусу контролю особистсоті (екстернальний / інтернальний) за 7ма шкалами: шкала загальної інтернальності; шкала інтернальності в області досягнень; шкала інтернальності в області невдач; шкала інтернальності в сімейних відносинах; шкала інтеранльності у виробничих відносинах; шкала інтернальності в міжособистісних взаєминах; шкала інтернальності у ставленні до здоров'я і хвороби. Методика містить 44 твердження які необхідно оцінити за 6-бальною шкалою за ступенем згоди чи незгоди. 
3. Рефлексивна методика «Моє ставлення до власного тіла» (О. Б. Станковської) є опитувальником, що уможливлює визначити рівень суб'єктивної значущості ставлення до власного тіла серед 4 шкал: 1. Відчужене ставлення; 2. Контролююче ставлення; 3. Дбайливе ставлення; 4. Розвивальне ставлення. Також, кожна зазначена шкала якісно характеризується параметрами: суб'єктивна значущість (мотиваційний компонент ставлення); сенс тіла (змістовний компонент ставлення); емоційний тон (емоційний компонент ставлення); чутливість (сенсорно-перцептивний компонент ставлення); пізнання тіла (когнітивний компонент ставлення); практика тіла (контактний компонент ставлення).

4. Опитувальник що визначає усвідомленість власного тіла Body Awareness Questionnaire (Shields, Mallory and Simon, 1989, переклад Марії Хайнц, 2017). Складається з 18 запитань на які треба відповісти за 7ми-бальною шкалою, оцінивши ступінь притаманності того чи іншого твердження для себе.

Дискримінантна валідність (від лат. - різниця, відмінність) - висновок про відмінність одного методу (методики, теста, заходу) від іншого, теоретично відрізняється від першого. Вона виражається у відсутності статистичної залежності між діагностичними показниками, що відображають концептуально незалежні властивості (Анастази, Урбина, 2007). Дискримінантна валідність нами була виявлена по відношенню до наступних методик:

1. Методика діагностики інтрацептивної чутливості (Т. Б. Хомуленко, К. М. Родіної), що $\epsilon$ україномовним модифікованим варіантом методики «Вибір дескрипторів інтрацептивних відчуттів» О. Ш. Тхостова, складається 3 переліку 81 інрацептивних відчуттів, які необхідно оцінити за ступенем вираженості від 0 до 5 балів. Критеріями оцінки виступають три стани: «здоровий», «хворий» та «при заняттях фізичною активністю». 
2. Методика незакінчених речень «Вербалізація тілесного Я» (Т. Б. Хомуленко, В.О. Крамченкова), призначена для дослідження психосоматичної компетентності (ПСК) як системи здатностей когнітивного компоненту тілесного Я, що пов'язана із прийняттям свого тіла, як складової цілісного організму, та обумовлює можливість ефекту саморегуляції заснованого на досвіді застосування внутрішнього діалогу з тілесним Я. За продовженням 16 незакінчених речень, уможливлює виявити кількісні й якісні показники за загальним показником вербалізації тілесного Я та валетністю ставлення до тіла.

Статистична обробка даних проводилася за допомогою пакету SPSS Statistics 21. У процедуру апробації було долучено 286 «умовно здорових» респондентів віком від 15 до 55 років, що утворили вибіркову сукупність дослідження.

Результати. Теоретичною основою створення опитувальника діагностики тілесного локусу контролю були:

- $\quad$ концепція локусу контролю Дж. Роттера (1966), як центральний структурний компонент теорії соціального научання, в якій локус контролю характеризує генералізовані стійки очікування, що $є$ втіленням минулого досвіду та пояснює поведінку, стабільність і єдність особистості;

- концепції реципрокного детермінізму та каузальної атрибуції (А. Бандура (1977), Ф. Хайдер (1958), Б. Вайнер (1970), в яких локалізація контролю в різних аспектах життєдіяльності $\epsilon$ визначальним чинником не лише поведінки, а суб'єктивного ставлення до відповідальності за події, що відбуваються (Хьелл, Зиглер, 2008);

- $\quad$ уявлення про профіль суб'єктивного контролю (С.Ф. Бажин, Є.А. Голинкін, Л.М. Еткінд, 1984), а саме відмінностями у прояві інтернальності, як особистісної риси, у різних ситуаціях та сферах активності;

- уявлення про роль інтернальності у клініці соматичних та психосоматичних розладів, а також зв'язку 
тілесного досвіду та смислового аспекту особистості (Сидоров, 2012; Василенко, Селин, Мангушев, 2016);

- визначення М. Сандомірського (2005) про локус тілесного контролю, як зв'язок локалізації тілесних відчуттів із усвідомленням власного психоемоційного стану та ступенем самоконтролю;

- визначення основних сфер ставлення до тілесного (сфера здоров'я і хвороби; сфера краси і зовнішності; сфера харчової поведінки; сфера сексуальної поведінки; сфера фізичної активності і спорту) як ідентифікаторів тілесного локусу контролю (Т.Б. Хомуленко, В.О. Крамченкова, Д.М. Туркова, 2019).

Отже, тілесний локус контролю визначається, як тенденція приписувати причини того, що відбувається 3 тілом у сфері фізичної активності і здоров'я, аліментарної і сексуальної поведінки зовнішнім або внутрішнім чинникам. При цьому, інтернальний тілесний локус контролю - тенденція бачити причини того, що відбувається 3 тілом у власній активності і схильність до прийняття відповідальності за стан і особливості функціонування власного тіла, а екстернальний тілесний локус контролю - навпаки приписування зовнішніх причин того, що відбувається з тілом.

Авторська методика діагностики тілесного локусу контролю (ТЛК) переслідує мету визначити спрямованість ставлення особистості до власного тіла (інтернальне / екстернальне). У зміст «Опитувальника тілесного локусу контролю (ТЛК)» було включено пари протилежних (полярних) тверджень, що сформульовані у відповідності до основних сфер тілесного та характеризують приписування внутрішніх або зовнішніх причин того, що відбувається з тілом.

Стандартизація методики відбувалася згідно вимог експериметальної психології щодо розробки вимірювальних інструментів й законів психометрики. 
Шляхом деревовидної кластерізації нами було виділено статистично значущі класи тверджень, що відповідають 5 сферам ставлення до тілесного: сфера здоров'я і хвороби; сфера краси i зовнішності; сфера харчової поведінки; сфера сексуальної поведінки; сфера фізичної активності і спорту. Частотний аналіз експертних виборів уможливив утворити перелік 320 пар протилежних тверджень, яким надається перевага за оцінювальною шкалою. Для кожного твердження досліджуваним пропонувалося вибрати одну із семи варіантів відповідей згідно зі шкалою 7-бальною Лайкерта «-3, -2, -1, 0, $+1,+2,+3 »$, в який відповіді розподіляються за ступенем згоди 3 твердженням: «зовсім не вірно», «не вірно», «скоріше не вірно», «не можу визначитись», «скоріше вірно, ніж не вірно», «вірно», «повністю вірно». Досліджуваним пропонується інструкція наступного змісту: «Вам запропоновані пари протилежних тверджень. Ваше завдання - обрати одне з двох тверджень, 3 яким Ви більше погоджуєтесь, і відмітити одну з цифр 1, 2, 3, в залежності від того наскільки Ви впевнені у виборі (або 0 , якщо обидва твердження на Вашу думку однаково вірні)».

За критерієм інтернальності твердження опитувальника представлені висхідними та низхідними пунктами, що розміщені у змішаному порядку. При обробці даних у висхідних пунктах опитувальника відповіді «зовсім не вірно», «не вірно», «скоріше не вірно», «не можу визначитись», «скоріше вірно, ніж не вірно», «вірно», «повністю вірно» переводяться в бали від 1 до 7 , а в низхідних навпаки. від 7 до 1 . До висхідних пунктів відносяться 1,3, 4, 8, 9, 11, 12, 16, 17, до низхідних - 2, 5, 6, 7, 10, 13, 14, 15, 18, 19, 20.

Кількість отриманих балів знаходиться в межах інтервалу 20-140.

Опитувальник

ТЛК характеризується інтраіндивідуальною стійкістю та розподілом близьким до нормального. Перевірка показників діагностичного дослідження підкоренню закону нормального розподілу вибірки ( $\mathrm{M}=86,44$; 
$\mathrm{Me}=89$; Мо=87), показала допустимі показники асиметрії ($0,536)$ та ексцесу $(-0,578)$ емпіричної кривої по відношенню до теоретичної i дає підстави для перенесення отриманих результатів вибіркової сукупності на генеральну.

Статистична перевірка внутрішньої узгодженості опитувальника проводилася за критерієм альфа Кронбаха для шкали, що включає всі 20 пунктів (тверджень). Величина альфа Кронбаха для шкали із 20 пунктів склала 0,939, що є вищою за мінімально припустиму величину, яка становить 0,7 .

Побудова нормативної шкали. В таблиці 1 представлені описові статистики «Опитувальника тілесний локус контролю».

При розбивці на три інтервали граничні значення статистичної норми для показника інтернальності тілесного локусу контролю складає 58-115 бали. Отже, для значення в межах 20-57 балів характеризують низький рівень інтернальності тілесного локусу контролю, 58-115 балів середній рівень, 116-140 балів - високий рівень інтернальності.

Таблиия 1

Описові статистики «Опитувальника тілесний локус контролю»

\begin{tabular}{|c|c|c|c|c|}
\hline \multirow{2}{*}{$\begin{array}{l}\text { Показники } \\
\text { тілесного локусу контролю }\end{array}$} & \multicolumn{4}{|c|}{ Описові статистики } \\
\cline { 2 - 5 } & Mean & Min & Max & St.d. \\
\hline Інтернальність & 86,43 & 26,00 & 139,00 & 28,71 \\
\hline
\end{tabular}

Високий рівень інтернальності тілесного локусу контролю характеризує стабільну тенденцію бачити причини того, що відбувається 3 тілом у власній активності і схильність до прийняття відповідальності за стан і особливості функціонування власного тіла у більшості ситуацій життєдіяльності.

Середній рівень інтернальності тілесного локусу контролю відображує ситуативність та вибірковість в усвідомлені детермінації особливостей функціонування власного тіла. 
Низький рівень інтернальності тілесного локусу контролю описує стабільну та глобальну екстернальність в області тілесного, тобто приписування причин тілесного зовнішнім (середовищним) обставинам

За результатами кореляційного аналізу було доведено високу конвергентну валідність поданої методики (рис. 1).

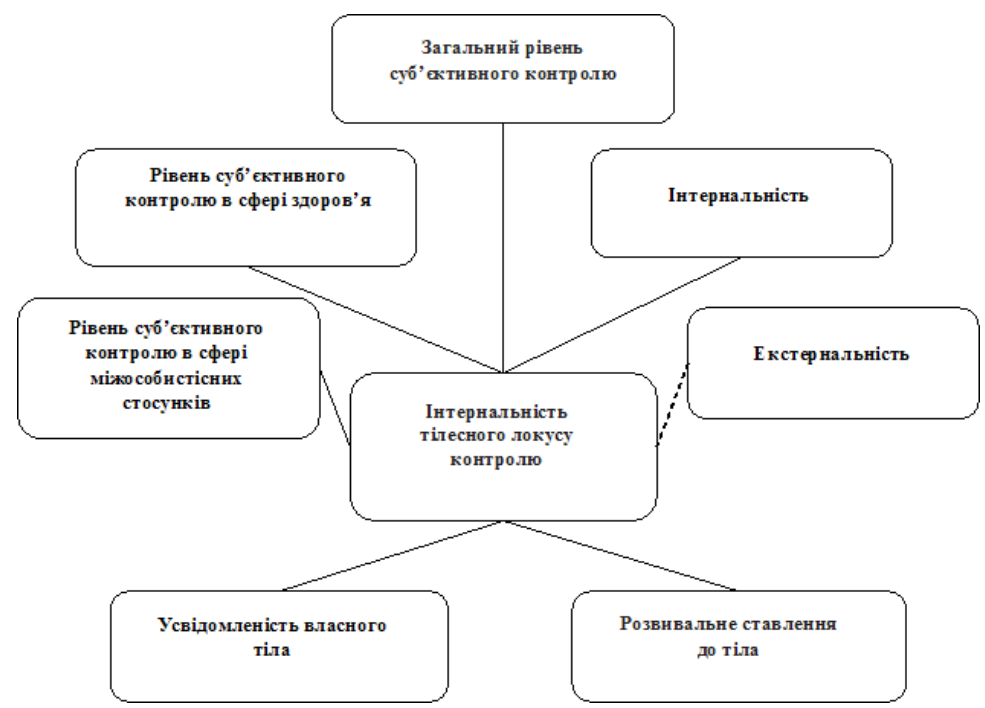

Рис. 1. Корелящійні зв'язки показнику інтернальності тілесного локусу контролю та показників локусу контролю, рівню суб'єктивного контролю у значущих сферах, усвідомленості та ставлення до власного тіла.

Примітка: - прямий кореляційний зв'язок, ---- зворотній кореляційний зв'язок.

Встановлено статистично значущі зв'язки між показником інтернальності тілесного локусу контролю та показниками загального рівню суб'єктивного контролю $(0,38, \mathrm{p}<0,001)$, рівню суб' Єктивного контролю в сфері здоров'я $(0,36, \mathrm{p}<0,001)$, рівню суб' єктивного контролю в сфері міжособистісних стосунків за 
методикою УСК Є. Ф. Бажина, С. А. Голикіної, А. М. Еткінда $(0,23, \mathrm{p}<0,01)$, показниками інтернальності $(0,28, \mathrm{p}<0,01)$ та екстернальності $(-0,28, \mathrm{p}<0,01)$ за тестом Дж. Роттера. Розвивальне ставлення до тіла за методикою О.Б. Станковської та усвідомленість власного тіла мають позитивний зв'язок із тілесним локусом контролю $(0,42, \mathrm{p}<0,001$ та $0,41, \mathrm{p}<0,001$ відповідно). Отже, запропонована методика вимірює саме усвідомлення детермінації особливостей функціонування власного тіла та характеризують приписування внутрішніх або зовнішніх причин того, що відбувається з тілом.

У таблиці 2 подано результати дискримінативної валідності методики ТЛК та опитувальника психосоматичних установок.

Таблиця 2

Кореляційні зв'язки показників інтрацепнтичвоъ чутливості та вербалізації «Тілесного Я» із тілесним локусом контролю

\begin{tabular}{|c|c|}
\hline $\begin{array}{c}\text { Мотиви та установки щодо } \\
\text { паління }\end{array}$ & $\begin{array}{c}\text { Показник інтернальності } \\
\text { тілесного локусу контролю }\end{array}$ \\
\hline $\begin{array}{c}\text { Інтрацептивна чутливість в } \\
\text { стані здоровий }\end{array}$ & $-0,01$ \\
\hline $\begin{array}{c}\text { Інтрацептивна чутливість в } \\
\text { стані хворий }\end{array}$ & 0,16 \\
\hline $\begin{array}{c}\text { Інтрацептивна чутливість при } \\
\text { заняттях физичною активністю }\end{array}$ & $-0,12$ \\
\hline $\begin{array}{c}\text { Рівень вербалізації тілесного } \\
\text { «Я» }\end{array}$ & 0,07 \\
\hline $\begin{array}{c}\text { Валентність ставлення до } \\
\text { тілесного «Я» }\end{array}$ & $-0,02$ \\
\hline
\end{tabular}

Визначення дискримінативної валідності здійснювалося шляхом встановлення значущості зв'язків показників методик «Вербалізація тілесного Я» (Т. Б. Хомуленко, В.О. Крамченкової), діагностики інтрацептивної чутливості 
(Т. Б. Хомуленко, К. М. Родіної) із показником інтернальності тілесного локусу контролю запропонованої методики. 3 таблиці 2 видно, що представлені показники за методиками визначають різні характеристики феноменів тілесності.

Другим етапом апробації було визначення надійності ТЛК процедурою ретестування. У результаті повторного діагностичного зрізу тієї ж вибірки (96 респондентів) через чотири тижні 3 дотриманням процедури повної ідентичності щодо первинного тестування, було отримано коефіцієнт кореляції що дорівнює коефіцієту надійності на рівні 0,75 при статистичній значущості p 0,01. Данні показники говорять про високий показник ретестової надійності, тобто сталості показників тестування протягом часу.

Таким чином методика ТЛК уповні пройшла перевірку на достовірність емпіричних даних і є дієвою для респондентів у віці від 15 до 55 років.

Отже, тілесний локус контролю - це свідома чи несвідома спрямованість фокусу уваги особистсоті на інтерпретацію стану тілесного Я й тілесних відчутів зокрема, мотивуючи цей стан зовнішніми (екстернальний тип) чи внутрішніми каузальними зв'язками (інтернальний тип). 3 точки зору психосоматичних феноменів нормального функціонування й психосоматичної компетентності ефективним локусом тілесного контролю $є$ інтернальний, а корелятом виникнення психосоматичної особистості виступає тілесний локус контролю - екстернальний. Так як тілесний локус контролю може функціонувати на свідомому чи несвідомому рівнях, то 3 розрахунку розвивальної й психотерапевтичної роботи доцільним $є$ розвиток особистості 3 інтернальним локусом тілесного контролю, себто типу особистості під назвою тілесний інтернал. У разі виявлення ровитку особистості за типом тілесного екстерналу $є$ прецидентом до корекційного втручання та пропедевтико-профілактичних заходів. Несвідомий тілесний інтернал також потрапляє до групи ризику, 
адже тип його саморегуляції більше нагадує механізм захисту, ніж свідому стратегію. Тож, метою корекційно-розвивальної роботи 3 тілесним локусом контролю є досягнення свідомого рівня тілесної саморегуляції в якості копінгово стратегії особистості як свідомої реакції на подолання несприятливих стресових чинників, що зазвивчай обумовлюють соматизації різного типу складності.

Висновки. Запропонована психодіагностична методика «Тілесний локус контролю» відповідає сучасним вимогам до психометричного обгрунтування особистісних опитувальників. Психометричними ідентифікаторами тілесного локусу контролю визначенно ставлення до основних сфер тілесного - сфери здоров'я і хвороби; краси і зовнішності, харчової та сексуальної поведінки, фізичної активності i спорту. Стандартизація опитувальника показала його високу тест-ретестову надійність та валідність. Опитувальник може бути використаний для психодіагностики у структурі досліджень 3 психосоматичної проблематики та реалізації оздоровчих психотехнологій.

Перспективним напрямком подальших досліджень може бути визначення взаємозв'язків тілесного локусу контролю та інтенсивності суб'єктивного емоційного переживання фізичного самопочуття.

\section{Література}

Анастази, А., Урбина, С. (2007). Психологическое тестирование. СПб.: «Питер», 688 с.

Бажин Е. Ф., Голынкина Е. А., Эткинд А. М. (1984). Метод исследования уровня субъективного контроля Психологический журнал. 5 (3). С. 152-162.

Василенко, Т. Д., Селин, А. В., Мангушев, Ф. Ю. (2016). Смысловые аспекты телесного опыта хронического соматического заболевания. Курский научно-практический вестник Человек и его здоровье. 2. С.116-121.

Елисеев, О. П. (2019). Практикум по психологии личности. Москва: «Юрайт»,. 390 с. 
Повякель, Н. І. (2005). Теорія соціального научання (Дж. Роттер ) СПб.: «Питер». 49 с.

Карелин, А.А. (2007). Психологические тесты. М.: «Эксмо». 416 c.

Сандомирский, М. Е. (2005). Психосоматика и телесная психотерапия: Практическое руководство. М.: Независимая фирма «Класс»,. 592с.

Сидоров, А.В. (2012). Исследование стилей пищевого поведения и психологических особенностей клиентов с алиментарным ожирением Медицинская психология в России: электрон. науч. журн. 5 (16), [Електронний ресурc] URL: http://medpsy.ru

Станковская, Е.Б. (2011). Типы и структура отношения женщины к себе в аспекте телесности: дисс. ... канд. психол. наук: 19.00.01. Москва,. 231с.

Хомуленко, Т. Б., Крамченкова, В. О. (2016). Методика проективної діагностики тілесного Я. Науковий вісник Херсонського державного університету. Серія «Психологічні науки . 5 (2). С.39-45.

Хомуленко, Т. Б., К Крамченкова, В. О., Туркова, Д. М. (2019). Тілесний локус контролю як копінг. Особистість у кризових умовах та критичних ситуаціях життя: матеріали V Міжнародної науковопрактичної конференції. Суми: Вид-во СумДПУ імені А. С. Макаренка. С.361-363

Хомуленко, Т. Б., Родіна, К. М. (2017). Роль імагінації у функціонуванні інтрацептивної чутливості особистості в юнацькому віці. Вісник ХНПУ імені Г. С. Сковороди. Психологія. 56. С.269-283.

Хьелл, Л., Зиглер, Д. (2008) Теории личности. СПб.: «Питер». $607 \mathrm{c}$.

Bandura, A. (1977). Self-efficacy: Toward a unifying theory of behavior change Psychological Review. 84. P. 191-215.

Heider, F. (1958). The psychology of interpersonal relations. New York: John Wiley \& Sons. 322 p.

Rotter, J. B. (1966). Generalized expectancies for internal versus external control of reinforcement // Psychological Monographs. 80 (1). P. 128.

Shields, S. A., Mallory, M. E., \& Simon, A. (1989). The Body Awareness Questionnaire: Reliability and validity. Journal of Personality Assessment, 53, P. 802-815. 
Weiner, B. (1970). An attributional analysis of achievement motivation Journal of Personality and Social Psychology. (15) P. 1-20.

\section{Бланк методики Тілесний локус контролю (ТЛК)}

\begin{tabular}{|c|c|c|c|c|c|c|c|c|c|}
\hline 1. & $\begin{array}{l}\text { Здоров'я }- \text { це } \\
\text { хороша } \\
\text { спадковість } \\
\text { турбота батьків }\end{array}$ & -3 & -2 & -1 & 0 & +1 & +2 & +3 & $\begin{array}{l}\text { Здоров’я - це плід } \\
\text { зусиль людини і її } \\
\text { способу життя }\end{array}$ \\
\hline 2. & $\begin{array}{l}\text { Відчуття власної } \\
\text { краси } \quad \text { залежить } \\
\text { від самої людини }\end{array}$ & -3 & -2 & -1 & 0 & +1 & +2 & +3 & $\begin{array}{l}\text { Людина відчуває } \\
\text { себе красивою, } \\
\text { коли ій про це } \\
\text { кажуть }\end{array}$ \\
\hline 3. & $\begin{array}{lr}\text { Якщо } & \text { не } \\
\text { привчили } \\
\text { дитинства } \\
\text { займатися } \\
\text { спортом, } \\
\text { людина і не буде } \\
\text { цим займатися }\end{array}$ & -3 & -2 & -1 & 0 & +1 & +2 & +3 & $\begin{array}{l}\text { У будь-якому віці } \\
\text { можна почати } \\
\text { займатися } \\
\text { спортом було б } \\
\text { бажання }\end{array}$ \\
\hline 4. & $\begin{array}{l}\text { Краса } 3 \text { віком } \\
\text { в’яне }\end{array}$ & -3 & -2 & -1 & 0 & +1 & +2 & +3 & $\begin{array}{l}\text { Активна } \\
\text { особистість може } \\
\text { бути красивою в } \\
\text { будь-якому віці }\end{array}$ \\
\hline 5. & $\begin{array}{lr}\text { Увага до власних } \\
\text { відчуттів під час } \\
\text { сексу } \\
\text { можливість } \\
\text { отримати біл } \\
\text { насолоди }\end{array}$ & -3 & -2 & -1 & 0 & +1 & +2 & +3 & $\begin{array}{lr}\text { Увага } & \text { за } \\
\text { перебігом } & \text { моїх } \\
\text { відчуттів під час } \\
\text { сексу - справа } \\
\text { партнера }\end{array}$ \\
\hline 6. & $\begin{array}{lr}\text { Кількість } & \text { їжі і } \\
\text { харчовий } & \text { режим } \\
\text { людина } & \text { має } \\
\text { контролювати для } \\
\text { забезпечення } \\
\text { власного здоров'я }\end{array}$ & -3 & -2 & -1 & 0 & +1 & +2 & +3 & $\begin{array}{lr}\text { Коли і } & \text { скільки } \\
\text { людина } & \text { їсть } \\
\text { залежить } & \text { від } \\
\text { зовнішніх } & \\
\text { обставин } & \end{array}$ \\
\hline 7. & $\begin{array}{lr}\text { Питання сексу } \\
\text { важлива сфера } \\
\text { знань, яка впливає } \\
\text { на повноцінне }\end{array}$ & -3 & -2 & -1 & 0 & +1 & +2 & +3 & $\begin{array}{l}\text { Обізнаність } \quad \text { у } \\
\text { питаннях сексу } \\
\text { має бути лише у } \\
\text { спеціалістів- }\end{array}$ \\
\hline
\end{tabular}


Вісник ХНПУ імені Г.С. Сковороди. Психологія. Випуск 62.

\begin{tabular}{|c|c|c|c|c|c|c|c|c|c|}
\hline & $\begin{array}{l}\text { функціонування } \\
\text { людини }\end{array}$ & & & & & & & & сексологів \\
\hline 8. & $\begin{array}{l}\text { Хворий не може } \\
\text { вплинути } \\
\text { перебіг хвороби }\end{array}$ & -3 & -2 & -1 & 0 & +1 & +2 & +3 & $\begin{array}{lr}\text { Завжди } & \text { частина } \\
\text { відповідальності } \\
\text { за } & \text { перебіг } \\
\text { хвороби } & \\
\begin{array}{l}\text { покладена } \\
\text { хворого. }\end{array} & \text { на }\end{array}$ \\
\hline 9. & $\begin{array}{lr}\text { Більшість } & \text { людей } \\
\text { займається } & \\
\text { спортом } \\
\text { компанії }\end{array}$ & -3 & -2 & -1 & 0 & +1 & +2 & +3 & $\begin{array}{l}\text { Людина сама } \\
\text { приймає рішення } \\
\text { чи займатися } і \text { ій } \\
\text { спортом }\end{array}$ \\
\hline 10. & $\begin{array}{l}\text { Приваблива } \\
\text { зовнішність може } \\
\text { бути результатом } \\
\text { власних зусиль }\end{array}$ & -3 & -2 & -1 & 0 & +1 & +2 & +3 & $\begin{array}{l}\text { Приваблива } \\
\text { зовнішність } \\
\text { вроджена } \\
\text { особливість } \\
\text { людини }\end{array}$ \\
\hline 11. & $\begin{array}{l}\text { Задоволеність } \\
\text { сексі - справа } \\
\text { випадку }\end{array}$ & -3 & -2 & -1 & 0 & +1 & +2 & +3 & $\begin{array}{l}\text { Задоволеність у } \\
\text { сексі - справа } \\
\text { активного } \\
\text { взаєморозуміння } \\
\text { партнерів }\end{array}$ \\
\hline 12. & $\begin{array}{l}\text { Значення якісного } \\
\text { харчування для } \\
\text { людини } \\
\text { перебільшують }\end{array}$ & -3 & -2 & -1 & 0 & +1 & +2 & +3 & $\begin{array}{lr}\text { Якісне } & \\
\text { харчування } & - \\
\text { обов'язок } & \\
\text { кожного, } & \text { хто } \\
\text { турбується } & \text { про } \\
\text { власний організм }\end{array}$ \\
\hline 13. & $\begin{array}{lr}\text { Зусилля } & \text { хворого } \\
\text { та його } & \text { намір } \\
\text { одужати } & - \\
\text { запорука } & \\
\text { подолання } \\
\text { хвороби }\end{array}$ & -3 & -2 & -1 & 0 & +1 & +2 & +3 & $\begin{array}{lr}\text { Хороший } & \text { лікар i } \\
\text { якісні } & \text { ліки } \\
\text { вилікують } & \\
\text { хворого } & \text { навіть } \\
\text { тоді, коли він не } \\
\text { має бажання } \\
\text { видужати }\end{array}$ \\
\hline 14. & $\begin{array}{l}\text { Власну } \\
\text { сексуальну } \\
\text { привабливість } \\
\text { можна } \\
\text { контролювати }\end{array}$ & -3 & -2 & -1 & 0 & +1 & +2 & +3 & $\begin{array}{l}\text { Сексуальна } \\
\text { привабливість } \\
\text { природна } \\
\text { властивість } \\
\text { людини }\end{array}$ \\
\hline
\end{tabular}


Хомуленко Т. та ін. Методика діагностики тілесного локусу...

\begin{tabular}{|c|c|c|c|c|c|c|c|c|c|}
\hline & & & & & & & & & \\
\hline 15. & $\begin{array}{l}\text { Люди займаються } \\
\text { спортом для } \\
\text { задоволення } \\
\text { власної потреби у } \\
\text { фізичній } \\
\text { активності }\end{array}$ & -3 & -2 & \begin{tabular}{|l|}
-1 \\
\end{tabular} & 0 & +1 & +2 & +3 & $\begin{array}{l}\text { Люди займаються } \\
\text { спортом тому, що } \\
\text { це модно }\end{array}$ \\
\hline 16. & $\begin{array}{l}\text { Краса не залежить } \\
\text { від способу життя }\end{array}$ & -3 & -2 & -1 & 0 & +1 & +2 & +3 & $\begin{array}{l}\text { Краса } є \text { результат } \\
\text { певного способу } \\
\text { життя }\end{array}$ \\
\hline 17. & 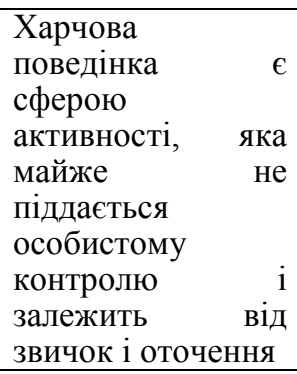 & -3 & -2 & \begin{tabular}{|l}
-1 \\
\end{tabular} & 0 & +1 & +2 & +3 & $\begin{array}{l}\text { Харчова } \\
\text { поведінка } \\
\text { сферою } \\
\text { активності } \\
\text { людини, } \\
\text { піддається } \\
\text { власному } \\
\text { контролю } \\
\text { вдосконаленню }\end{array}$ \\
\hline 18. & $\begin{array}{lr}\text { Доклавши } & \text { зусиль } \\
\text { людина } \quad 3 & \text { часом } \\
\text { може } & \text { стати } \\
\text { здоровішою } & \end{array}$ & -3 & -2 & -1 & 0 & +1 & +2 & +3 & 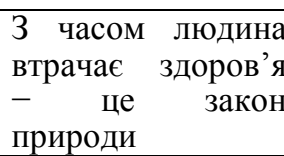 \\
\hline 19. & $\begin{array}{l}\text { Гармонійність } \\
\text { рухів, спритність } \\
\text { дій та стрункість } \\
\text { статури } \\
\text { результатом } \\
\text { фізичної } \\
\text { активності } \\
\text { занять спортом }\end{array}$ & -3 & -2 & \begin{tabular}{|l|}
-1 \\
\end{tabular} & 0 & +1 & +2 & +3 & $\begin{array}{l}\text { Гармонійність } \\
\text { рухів, спритність } \\
\text { дій та стрункість } \\
\text { статури } \\
\text { вродженими } \\
\text { особливостями } \\
\text { людини }\end{array}$ \\
\hline 20. & $\begin{array}{l}\text { Контроль } \\
\text { харчуванні } \\
\text { можливість дає } \\
\text { поєднати якість } \\
\text { їжі } 3 \text { відчуттям } \\
\text { насолоди }\end{array}$ & -3 & -2 & \begin{tabular}{|l|}
-1 \\
\end{tabular} & 0 & +1 & +2 & +3 & $\begin{array}{l}\text { Здорова } \\
\text { несмачна }\end{array}$ \\
\hline
\end{tabular}


Вісник ХНПУ імені Г.С. Сковороди. Психологія. Випуск 62.

Подальша обробка даних передбачає переведення «сирих» балів у стандартні величини за допомогою шкал «прямих» та «обернених» відповідей поданих у ключі.

Ключ до ТЛК

\begin{tabular}{|c|c|c|}
\hline Варіант відповіді & $\begin{array}{c}\text { В прямих значеннях } \\
\text { за пунктами } \\
1,3,4,8,9,11,12,16,17\end{array}$ & $\begin{array}{c}\text { В обернених } \\
\text { значеннях за } \\
\text { пунктами } \\
2,5,6,7,10,13,14, \\
15,18,19,20 \\
\end{array}$ \\
\hline «зовсім не вірно» & 1 бал & 7 балів \\
\hline «не вірно» & 2 бали & 6 балів \\
\hline «скоріше не вірно» & 3 бали & 5 балів \\
\hline $\begin{array}{c}\text { «не можу } \\
\text { визначитись» }\end{array}$ & 4 бали & 4 бали \\
\hline $\begin{array}{c}\text { «скоріше вірно, ніж } \\
\text { не вірно» }\end{array}$ & 5 балів & 3 бали \\
\hline «вірно» & 6 балів & 2 бали \\
\hline «повністю вірно» & 7 балів & 1 бал \\
\hline
\end{tabular}

Оригінальний рукопис отриманий 7 грудня 2019 року

Стаття прийнята до друку 16 грудня 2019 року 